\title{
Obtaining Bacteriocins by Chromatographic Methods
}

\author{
Valery Borzenkov ${ }^{*}$, Vladimir Surovtsev ${ }^{2}$, Ivan Dyatlov ${ }^{1,2}$ \\ ${ }^{1}$ Department of Diagnostic Preparations, State Research Center for Applied Microbiology and Biotechnology, \\ Serpukhov, Russia \\ ${ }^{2}$ Department of Molecular Microbiology, State Research Center for Applied Microbiology and Biotechnology, \\ Serpukhov, Russia \\ Email: ${ }^{*}$ vmborzenkov@mail.ru
}

Received 20 December 2013; revised 8 March 2014; accepted 22 March 2014

Copyright (C) 2014 by authors and Scientific Research Publishing Inc.

This work is licensed under the Creative Commons Attribution International License (CC BY).

http://creativecommons.org/licenses/by/4.0/

(c) (i) Open Access

\section{Abstract}

Bacteriocins are a large group of chromosome or plasmid-encoded and ribosomally synthesized low-molecular-weight ( 2 to $6 \mathrm{kDa}$ ) antimicrobial and amphiphilous peptides produced by $\mathrm{Gr}^{+}$or $\mathrm{Gr}^{-}$bacteria [1]. Their low toxicity as well as the absence of allergenicity and reactogenicity is confirmed by testing selected bacteriocins [2] [3]. Bacteriocins can be widely used as preservatives and antibiotic alternatives in medicine. Nisin, a Streptococcus lactis-derived bacteriocin, has been in practice in food industry for a long time. A relevant product contains about $2.5 \%$ of nisin. For medical use (e.g., when injected into the blood stream), highly purified drugs are required. However, the yield of bacteriocins accounts for no more than a few percents from the total activity in the culture liquid. In this paper, we propose methods (by example of two $B$. subtilis strains), allowing to increase the yield up to $\sim \mathbf{8 0} \%$. It is believed that other bacteriocins may be purified by these methods and with the same yield.

\section{Keywords}

Purification; Bacteriocins; Surface Cell Fragments; Hydrophobicity; Membranes; Ion-Exchange; Hydrophobic Chromatography

\section{Introduction}

Currently, the excessive appliance of antibiotics has led to wide spread occurrence a proliferation of pathogens resistant to different groups of these medicines. Antibiotics can be very toxic and allergenic to some people. For

\footnotetext{
*Corresponding author.
} 
example, the aminoglycoside antibiotics are toxic to the kidney tissue and the inner ear. Up to a quarter of patients receiving gentamicin experienced acute renal failure and a third of patients irreversibly reduced hearing. However, aminoglycoside antibiotics have no alternative for treatment of the infections caused by most resistant strains of Gr- microorganisms [4]. Therefore, the search and the use of drugs other than antibiotics are urgent.

Bacteriocins can be substances capable in some cases to replace antibiotics. However, high-purity bacteriocins are needed for medical applications. At the present, they are mainly obtained for structural research since the yield of the purified product was accounted for a few percents. The usual procedure involves the bacterocine precipitation of the culture liquid by ammonium sulfate, hydrophobic chromatography on oktyl Sepharose , ion exchange chromatography and high performance liquid chromatography [5]. Probably, the low yield of the purified product is one of the reasons for the lack of examples of medical use of bacteriocins. In any case, we have not found it described in the literature.

Objectives of our research were to purify two bacillus-derived bacteriocins up to the electrophoretically pure state and to achieve the bacteriocin yield of $80 \%$.

\section{Material and Methods}

\subsection{Producers}

Producers B. subtilis BSX and B. subtilis B-112 as well as indicators Salmonella enteritidis 237 (for B. subtilis B-112) and Listeria monocytogenes 716 were provided by the collection of the State Research Center for Applied Microbiology and Biotechnology (Russia).

\subsection{Cultivation of Bacteriocin Producers}

B. subtilis BSX and B. subtilis B-112 were cultured in a 7.5 bioreactor (Bioflo 110, News Brunswick Scientific, USA)containing 5 liters of the nutrient medium at $30^{\circ} \mathrm{C}$ for $12 \mathrm{~h}$ and $24 \mathrm{~h}$, respectively. Aeration was performed at $2.51 / \mathrm{min}$. The mixing speed depended on the concentration of dissolved oxygen $\left(\mathrm{pO}_{2} 10 \% / 450 \mathrm{rpm}\right)$. The original $\mathrm{pH}$ of the culture fluid was 7.2.

\subsection{Nutrient Media}

Nutrient medium for B. subtilis BSX contained (g/l): $\mathrm{K}_{2} \mathrm{HPO}_{4}-10.5 \mathrm{~g} ; \mathrm{KH}_{2} \mathrm{PO}_{4}-4.5 \mathrm{~g}$; $\left(\mathrm{NH}_{4}\right)_{2} \mathrm{SO}_{4}-1 \mathrm{~g}$; Citrate $\mathrm{Na}$, three-substituted $2 \mathrm{H}_{2} \mathrm{O}-0.5 \mathrm{~g}$; $\mathrm{MgSO}_{4} \cdot 7 \mathrm{H}_{2} \mathrm{O}-0.2 \mathrm{~g}$; Glucose-2 g.

A combined saline solution was sterilized at $1 \mathrm{~atm}$ for $30 \mathrm{~min}$. A glucose solution was sterilized at $0.5 \mathrm{~atm}$ for 30 min.

Nutrient medium for $B$. subtilis B-112 contained (g/l): Fish flour pancreatic hydrolyzate- $8.0 \mathrm{~g}$;

Peptone, enzymatic-8.0 g; NaCl-4.0 g; $\mathrm{MgSO}_{4} \cdot 7 \mathrm{H}_{2} \mathrm{O}-0.2 \mathrm{~g}$; Glucose-2 g; Yeast extract-5.0 g.

A combined solution was sterilized at $1 \mathrm{~atm}$ for $30 \mathrm{~min}$. A glucose solution was sterilized at $0.5 \mathrm{~atm}$ for 30 $\min$.

\subsection{Bacteriocin Purification}

\subsubsection{Method A}

Two liters of the culture fluid of B. subtilis BSX were centrifuged (10,000 g) for $10 \mathrm{~min}$ to remove cells. The pellet was decanted. $\mathrm{pH}$ of the supernatant was adjusted to 2.8 by adding $4 \mathrm{M} \mathrm{HCl}$ and kept at $4^{\circ} \mathrm{C}$ overnight. The fragments were separated by centrifugation $(12,800 \mathrm{~g})$ for $10 \mathrm{~min}$. The fragment pellet was diluted with 25 $\mathrm{ml}$ of water and suspended. $25 \mathrm{ml}$ of isopropanol was then added and mixed. The resultant suspension was kept at $4^{\circ} \mathrm{C}$ for $1 \mathrm{~h}$ with shaking and centrifuged $(12,800 \mathrm{~g})$ for $10 \mathrm{~min}$. The produced pellet was removed. Isopropanol was evaporated in a rotor evaporator at $60^{\circ} \mathrm{C}$. Afterwards $25 \mathrm{ml}$ of water and carbon $(3 \mathrm{mg} / \mathrm{ml})$ were added. The suspension was kept at $4^{\circ} \mathrm{C}$ for an hour. Then carbon was removed by centrifugation at 10,000 $\mathrm{g}$ for $10 \mathrm{~min}$. The resultant solution was filtered through a cellulose membrane ( $>10 \mathrm{kDa}$; Millipore). $1.0 \mathrm{ml}$ solution was brought on a Sephadex G-25 column $(1.5 \times 35 \mathrm{~cm})$ balanced with $5 \mathrm{mM}$ phosphate buffer, $\mathrm{pH} 7.0$ in the presence of $50 \mathrm{mM}$ sodium sulfate. The yield of the purified bacteriocin was spectrophotometrically measured at $205 \mathrm{~nm}$. 


\subsubsection{Method B}

Two liters of the culture fluid of $B$. subtilis B-112 were centrifuged (10,000 g) for 10 min to remove cells. The pellet was decanted. $\mathrm{pH}$ of the supernatant was adjusted to 2.8 by adding $4 \mathrm{M} \mathrm{HCl}$ and kept at $4^{\circ} \mathrm{C}$ overnight. The fluid was centrifuged (12,800 g) for $10 \mathrm{~min}$. The pellet was removed and supernatant was used for further investigation.

To determine appropriate conditions for cation exchange chromatography, a battery of test columns was prepared. We used $2 \mathrm{ml}$ syringes as columns in our research. Each column was loaded with $\mathrm{Na}^{+} \mathrm{CM}$ cellulose and balanced with $0.05 \mathrm{M}$ acetate buffer (pH 5.0 and 5.5), phosphate buffer (pH 6.0, 6.5, 7.0 and 7.5), and tris-HCl (pH 8.0 and 8.5), respectively.

A $2 \mathrm{M} \mathrm{NaOH}$ solution was dropped into $0.9 \mathrm{ml}$ of the supernatant with fragments removed beforehand at $\mathrm{pH}$ 2.8 to obtain $\mathrm{pH}$ needed. An appropriate $0.5 \mathrm{M}$ buffer in the volume of $0.1 \mathrm{ml}$ was added as well. The resultant solution was applied to each column, and 12 milliliters of $0.05 \mathrm{M}$ buffer were then introduced into each column. Aliquots of $1 \mathrm{ml}$ were taken to analyze for a bacteriocin. The same buffers along with $3 \mathrm{M} \mathrm{NaCl}$ were added to the columns whose eluates did not contain the bacteriocin.

In that way an approximate isoelectric point of the bacteriocin (from $\mathrm{pH} 7.0$ to 7.5) and the eluting buffer were determined. The column containing the selected buffer was stepwise loaded with one milliliter of the cellfree supernatant in the same buffer $(0.05 \mathrm{M}$ acetate buffer, $\mathrm{pH}$ 5.5). Then $1 \mathrm{ml}$ eluate fractions were analyzed for the presence or absence of the bacteriocin. Approximate capacity of the ion exchanger as well as the size of the column was determined.

In case of the experimental $\mathrm{Na}^{+} \mathrm{CMC}$ column $(2 \times 40)$ it was balanced with the same buffer. Two liters of the fragment-free supernatant adjusted to $\mathrm{pH} 5.5$ were added. After passing the supernatant, column is intensively washed with $3 \mathrm{l}$ of $0.05 \mathrm{M}$ acetate buffer, $\mathrm{pH} 5.5$ and $3 \mathrm{l}$ of water to remove colored impurities. Then $0.4 \mathrm{M}$ glycine-HCl buffer, $\mathrm{pH} 2.5$ was passed through a column. The eluate (fractions per $5 \mathrm{ml}$ ) was collected in a fraction collector. In each vial meaning of $\mathrm{pH}$ was adjusted to 4.0 and the active fractions were pooled. Active fractions were passed through a cellulose membrane cutting molecular weight more $10 \mathrm{kDa}$ and were combined. $1 \mathrm{ml}$ was brought on a Sephadex G-25 column balanced with $7 \mathrm{mM}$ phosphate buffer (pH 7.0) in the presence of $50 \mathrm{mM}$ $\mathrm{Na}_{2} \mathrm{SO}_{4}$. The bacteriocin concentration at $205 \mathrm{~nm}$ was measured.

\subsection{Dialysis}

10 milliliters of the cell-free supernatant of B. subtilis BSX or B. subtilis B-112 were introduced into each dialysis sac. Dialysis was carried out against $0.02 \mathrm{M} \mathrm{NaCl}$ at $4{ }^{\circ} \mathrm{C}$ for 10 days. Samples were daily taken, and activities of the bacteriocins were measured. After the removal of fragments a B. subtilis B-112 bacteriocin solution was placed into a separate sac. The next day a sample was taken to determine activity of the bacteriocin.

\subsection{Determination of Bacteriocin Activity}

Activities of the bacteriocins against test cultures were measured. For this purpose $10 \mu \mathrm{l}$ from each two-fold dilution were spread over surfaces of fresh lawns produced by L.monocytogenes 716 and S.enteritidis 237. The specific activity $(\mathrm{AU} / \mathrm{ml})$ was the maximum dilution at which an area of growth inhibition of the test cultures was visualized. Activities of the bacteriocins were determined in a similar way at all stages of isolation and purification of the bacteriocins.

Post-cultivation activities of the bacteriocins in supernatants were determined. For this purpose the culture fluid was centrifuged $(10,000 \mathrm{~g})$ for $10 \mathrm{~min}$, and $\mathrm{pH}$ of the supernatant was adjusted to 7.0. A supernatant aliquot was treated with a catalase solution in the final concentration of $50 \mu \mathrm{g} / \mathrm{ml}$ to eliminate a potential effect of $\mathrm{H}_{2} \mathrm{O}_{2}$. Then, it was sterilized through a $0.22 \mu \mathrm{m}$ bacterial filter membrane and two-fold diluted with a saline solution. The titer was determined.

\section{Results and Discussion}

In the 60s - 90s many powerful methods to purify proteins were discovered. Target and admixed proteins can be separated by their molecular weights, charges, hydrophobic properties, and effects of salts (mainly sulfates) and organic solvents (acetone or ethanol). They can be also separated by their adsorbing potentialities, resistance to $\mathrm{pH}$ and temperature, antibody affinity, as well as by types of substrates and inhibitors (in case of enzymes), 
cyanurchloride derivatives, etc. It is possible to purify a protein and to produce it in practically significant amounts by using some of these methods. However, the choice of an appropriate way of purification may be a problem [6].

Like any other proteins bacteriocins are polypeptides, and some of these procedures can be therefore used for their purification as well. Since physicochemical properties of bacteriocins are similar, some of these methods can be acceptable for purification of many or even all of them. In contrast to proteins low-molecular-weight bacteriocins lack of spatial structures and are resistant to $\mathrm{pH}$ and temperature fluctuations, to organic solvents, and can be therefore treated as traditional organics.

Since all bacteriocins are amphiphilic, highly hydrophobic bacteriocins can be subjected to hydrophobic chromatography, provided that their specific properties are taken into account.

But some procedures of protein purification are not applicable for bacteriocin purification. For instance, the popular method of ammonium sulfate precipitation does not work for low-molecular-weight proteins. These proteins precipitate poorly even at $75 \%$ - $80 \%$ saturation, and when passing through dialysis sacs they are eliminated fully or in part. Therefore, this method is unacceptable for purification of low-molecular-weight bacteriocins either.

Nevertheless, according to reported data this method is often used to purify bacteriocins, commonly immediately after cell elimination. After cell removing and dialysis bacteriocins either maintain their full activity at $50 \%-60 \%$ saturation or lose it up to $40 \%$ even at saturation of $75 \%-80 \%$ (dialysis sacs to purify proteins are used) [7] [8]. Bacteriocins fully retaining activity after ammonium sulfate precipitation function as high-molecular proteins (e.g. $150 \mathrm{kDa}$ IgG precipitates at 40\% - 50\% saturation [9]). There are no arguments to speak about their aggregation (some peptides can aggregate at base $\mathrm{pH}$ ) and therefore, bacteriocins released to the culture fluid bind to "macromolecular particles". Since electrostatic bonds are weak in water due to the high dielectric constant, and hydrogen bonds are weak because of their competitiveness with water hydrogen bonds, the hydrophobic interaction might be expected.

The peptide secreted by $B$. subtilis BSX cells retained its entire activity after ammonium sulfate precipitation at $50 \%$ saturation. We used a hydrophobic component-free medium to isolate a B. subtilis BSX bacteriocin. It was suggested that bacteriocin adhered to hydrophobic surfaces of cells or their fragments, mainly to superficial ones, resulted from cultivation.

If so, a method could be elaborated to purify such bacteriocins by hydrophobic chromatography, where producer cells and their fragments would play a role of a "sorbent". Cell surfaces of many microorganisms are negatively charged at neutral pH. For example, Micrococcus lysodeicticus superficial pK is 3.5 [10] (N-acetylmuramic acid residues are responsible for peptidoglycane charge in such cells). The fragments are tiny and kept by the supernatant after centrifugation to remove cells. Their surfaces are much more than ones of cells and most of the molecules of the bacteriocin bound to them. By adjusting $\mathrm{pH}$ below 3.0, one lowers charge of the fragments thereby stimulating their precipitation. After centrifugation soluble admixtures are removed, and hydrophobic interactions between the bacteriocin and the fragment surfaces are broken by adding an alcohol miscible with water in any ratio (isopropanol in our research). Precipitated fragments are decanted, and the bacteriocin remains in the solution. The yield of the bacteriocin was $90 \%$ and greater of its total activity in the culture fluid. Subsequent steps including the treatment of the bacteriocin with carbon, and membrane filtration (Figure 1) did not influence much on its total activity. The final yield of the bacteriocin was $80 \%$. Since the bacteriocin activity on cells was as low as $5 \%$ to $7 \%$ of its total activity in the culture fluid, we didn't use cells to produce the bacteriocin.

Bacteriocins of the second group are less hydrophobic. They don't bind to the cell surface and therefore their precipitation occurs in part only (50\% activity at $80 \%$ saturation for B. subtilis B-112). Upon keeping dialysis sacs containing a cell-free suspension but with kept fragments at neutral $\mathrm{pH}$ for 10 days the original bacteriocin activity decreased by not more than $15 \%$, whereas the activity decreased fully overnight in the absence of the fragments. This observation suggests that fragments hinder the release of the bacteriocin from a dialysis sac. The fragments may also prevent the bacteriocin from adsorption at chromatographic stages and should be therefore removed. At the same time, ultrafiltration of a bacteriocin in the presence of the fragments with simultaneous retaining its activity is possible, if filter membrane pore sizes are allowed for $15 \mathrm{kDa}$ peptides and greater.

After fragment elimination low-hydrophobicity bacteriocins were subjected to ion exchange chromatography (most bacteriocins are cations at neutral $\mathrm{pH}$ ). The column containing balancing ion exchange buffer was washed to remove color uncharged admixes and other ballasts. CM cellulose was used as an ion exchanger. Ion ex- 


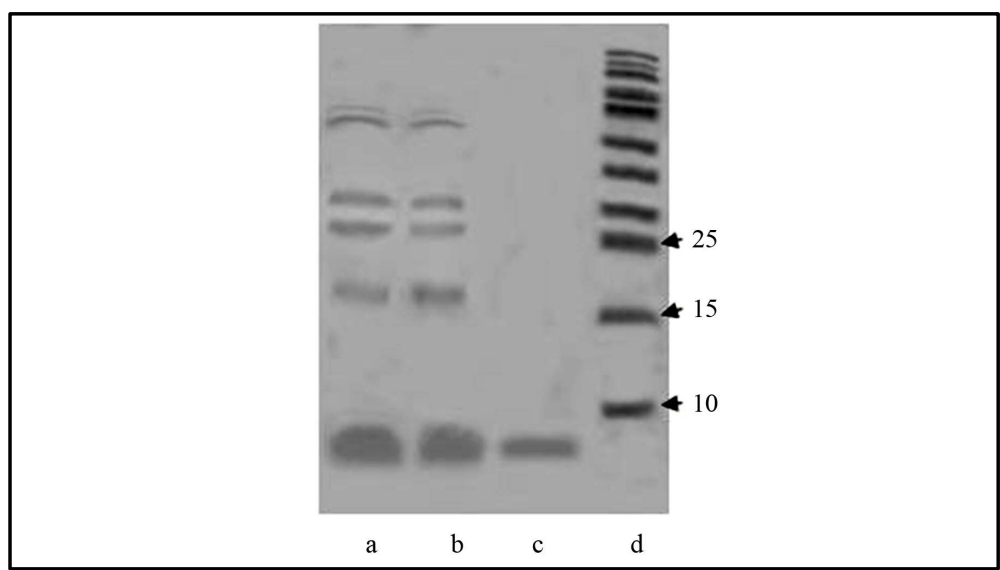

Figure 1. Electrophoregram of B. subtilis BSX bacteriocin purification. (a) Sample taken directly from the culture fluid; (b) Carbon post-treated sample (to remove color uncharged admixes); (c) Post-membrane filtration sample (bacteriocin); (d) Markers.

change chromatographic conditions were selected by testing a battery of test columns at different $\mathrm{pH}$. This method allows one to choose required elution conditions, appropriate column sizes, and approximate isoelectric points (in our case 7.2 ). However, the yield of the product varied greatly ( $25 \%$ to $40 \%$, average of $30 \%$, generalized data from 5 experiments, eluation by $0.05 \mathrm{M}$ acetic buffer with $1 \mathrm{M} \mathrm{NaCl}$ ).

That was a reason why we are then eluted the bacteriocin with $0.4 \mathrm{M}$ glycine-HCl buffer, $\mathrm{pH} 2.5$ (pK meaning of CM-sorbents is $\sim 4.0$ [11]). Under these conditions, the proteins usually are denatured. However, the bacteriocin goes out of column essentially $90 \%-100 \%$ of the total activity. The final yield of the bacteriocin after membrane filtration was $\sim 80 \%$.

Thus to purify a bacteriocin secreted by a producer a cell-free portion of the culture fluid should be brought to $\mathrm{pH}<3.0$. The resultant fragment pellet is diluted with isopropanol, and activities of the pellet and the supernatant are measured. If the pellet is active, purification is performed according to method A. Otherwise method B and appropriate ion exchangers and buffers determined by isoelectric points of bacteriocins are used (see Methods). It is unknown if there are cases when the pellet and the supernatant share activity, e.g. in the ratio 1:1. If it is true, then the pellet and the supernatant are treated by methods A and B, respectively.

The purified bacteriocins were quantified at $205 \mathrm{~nm}$ according to the following equation:

$$
E_{205}^{1 \mathrm{mg} / \mathrm{ml}}=27+120 \frac{A_{280}}{A_{205}}
$$

Use of this method is based on the fact that at $205 \mathrm{~nm}$ tryptophan, tyrosine, histidine, methionine and arginine absorb. High content nonaromatic aminoacids makes their contribution to the protein spectrum highly homogeneous. For the 12 proteins with very different amino acid composition variation of absorbtion of solution containing $1 \mathrm{mg} / \mathrm{ml}$ from the average value (31 units) not exceeded 2\% [12]. The method was intended for protein research, but it is not popular. But it has a number of advantages over routine measurements at $280 \mathrm{~nm}$. One of them is very important. To measure a polypeptide concentration at $205 \mathrm{~nm}$, no aromatic aminoacids in the composition of the polypeptide or calculation of their quantity per a macromolecule are required. On the other hand, different salts may adsorb at this wave length making requirements to the composition of buffers stringent. Concentrations of the bacteriocins produced by B. subtilis BSX and B. subtilis B-112 in the original culture fluid were $33 \mathrm{mg} / \mathrm{l}$ and $42 \mathrm{mg} / \mathrm{l}$, respectively.

\section{References}

[1] Riley, M.A. and Wertz, J.E. (2002) Bacteriocins, Evolution, Ecology and Application. Annual Review Microbiology, 7, 129-133.

[2] Cotter, P.D., Hill, C. and Ross, R.P. (2005) Bacteriocins: Developing innate Immunity for Food. Nature Review Microbiology, 3, 777-787. 
[3] Bilková, A., Sepova, H.K., Bilka, F. and Balázová, A. (2011) Bacteriocins Produced by Lactic Acid Bacteria. Ceska Slovenska Farmacia, 60, 65-72.

[4] Jankauskas, S.S., Carpenter, E.J., Morosanova, M.A. and Skulachev, V.P. (2012) Antioksidant SkQR1 Reduces Gentamicin-Induced Renal Failure and Hearing Loss. Biochemistry (Moscow), 77, 818-823.

[5] Carolissen-Mackay, V., Arendse, G. and Hastings, J. (1997) Purification of Bacteriocins of Lactic Acid Bacteria: Problems and Pointers. International Journal Food Microbiology, 34, 1-16.

[6] Scopes, R.K. (1982) Protein Purification. Principles and Practice. Springer-Verlag New York Heidelberg Berlin, 356 p.

[7] Parents, E. and Ricciardi, A. (1999) Production, Recovery and Purification of Bacteriocins from Lactic Acid Bacteria. Applied Microbiology and Biotechnology, 52, 628-638.

[8] Stern, N.J., Svetoch, E.A. and Levchuk, V.P. (2006) Isolation of a Lactobacillus salivarius Strain and Purification of Its Bacteriocin Which Is Inhibitory to Campylobacter jejuni in the Chicken Gastrointestinal System. Antimicrobial Agents and Chemotherapy, 50, 3111-3116.

[9] Brock, J. (1984) Isolation of Immunoglobulins. In: Frimel, H., Ed., Immunologische Arbeitemethoden, VEB Gustav Fischer Verlag, Jena, 390-412.

[10] Klyosov, A.A., Rabinowich, M.L. and Berezin, I.V. (1976) Kinetics of Enzymic Reactions in Heterogeneous Systems. Bioorganic Chemistry (Moscow), 2, 795- 802.

[11] Lurie, A.A. Sorbents and Chromatographic Carrying Agents. Chemistry, Moscow, 319 p.

[12] Scopes, R.K. (1974) Measurement of Protein by Spectrophotometry at 205 nm. Analytical Biochemistry, 59, $277-282$.

\section{Abbreviations \\ $\mathrm{Gr}^{+}: \quad$ Gram Positive \\ $\mathrm{Gr}^{-}$: $\quad$ Gram Negative \\ kDa: Kilodalton \\ AU: Arbitrary Unit}

